\title{
REG1A wt Allele
}

National Cancer Institute

\section{Source}

National Cancer Institute. REG1A wt Allele. NCI Thesaurus. Code C131323.

Human REG1A wild-type allele is located in the vicinity of $2 \mathrm{p} 12$ and is approximately $3 \mathrm{~kb}$ in length. This allele, which encodes lithostathine-1-alpha protein, may play a role in the modulation of the proliferation of both islet cells and neurons. Gene expression may be associated with both diabetogenesis and pancreatic lithogenesis. 